\title{
Development and validation of the General Attitude towards Medication Questionnaire (GAMQ)
}

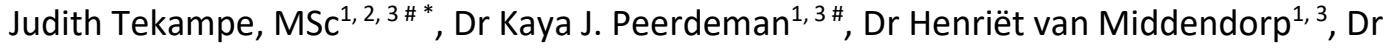 \\ Antoinette I.M. van Laarhoven ${ }^{1,3,4}$, Dr Ralph C.A. Rippe ${ }^{5}$, Prof Madelon L. Peters ${ }^{6}$, Prof Andrea W.M. \\ Evers $^{1,2,3,4}$ \\ \# joint first authorship
}

1. Health, Medical and Neuropsychology Unit, Institute of Psychology, Faculty of Social and Behavioural Sciences, Leiden University, Leiden, the Netherlands.

2. Department of Medical Psychology, Radboud university medical center, Nijmegen, the Netherlands.

3. Leiden Institute for Brain and Cognition, Leiden University, Leiden, the Netherlands

4. Department of Psychiatry, Leiden University Medical Center, Leiden, the Netherlands

5. Research Methods and Statistics, Institute of Education and Child Studies, Leiden University, Leiden, the Netherlands

6. Department of Clinical Psychological Science, Maastricht University Maastricht, the Netherlands.

* Corresponding author: Judith Tekampe; Leiden University; Wassenaarseweg 52, 2333 AK Leiden; j.tekampe@fsw.leidenuniv.nl

Note: The current version of the article is a preprint and has not yet been subject to peer review. It is not the final published version.

Conflicts of Interest and Source of Funding: The authors declare no financial, consultant, institutional and other relationships that might lead to bias or a conflict of interest. This research was funded by an Innovation Scheme Vidi Grant from the Netherlands Organization for Scientific Research (NWO) and an ERC Consolidator Grant from the European Research Council (ERC), both granted to A.W.M. Evers. 


\section{Abstract (MAXIMUM 250 words, now 250 words)}

Background: Attitudes towards medication can affect treatment outcomes and adherence through mechanisms such as placebo and nocebo effects. Although both negative and positive attitudes towards medication are of importance, previous research mainly investigated the impact of negative attitudes towards medication. This focus is also reflected in existing self-report scales, most of which measure negative beliefs about medication in general and/or focus on specific medication. To assess both negative and positive attitudes towards medication in general, the General Attitude towards Medication Questionnaire (GAMQ) was developed.

Method: For the GAMQ, 12 items largely based on existing questionnaires were selected. It was validated in 4 Dutch samples: 2 samples of 508 and 279 respondents of the general population, and 2 samples of 121 patients with rheumatoid arthritis and 70 patients with atopic dermatitis.

Results: Factor analyses indicated three subscales representing "Trust in medication", "Concerns about medication", and "Reluctance to use medication", which were structurally stable across the samples. The total scale showed good internal consistency. Medium to strong correlations with other measures of general medication attitude (e.g. BMQ-G), indicated good convergent validity. Furthermore, exploring its predictive validity indicated that the GAMQ correlated with expected medication outcomes.

Conclusion: Results suggest that the GAMQ is suitable for assessing general medication attitudes, both negative and positive, in a wide variety of research settings and in various patient populations. Due to its balanced nature, the GAMQ may be especially informative when investigating predictors of treatment outcomes and adherence, as well as determinants of placebo and nocebo effects.

Keywords: Medication, Attitude, Questionnaire development, Expectancies, Placebo effects, Nocebo effects

Acknowledgements: The authors thank Prof Annette van der Helm and Prof Tom Huizinga for their help in accessing the Leiden Early Arthritis Cohort, Dr Adriana Lavrijsen for her assistance in recruiting patients with Atopic Dermatitis, Dr Esther A. Habers and Dr Rebecca S. Schaefer for collaboration in data collection, Dr Maria Sherwood-Smith (Dipl. SIGV) for forward-backward translation, Prof Floris W. Kraaimaat for help with item selection. 


\section{Introduction}

Attitudes towards medication have been identified as important predictors of treatment outcomes (1-3) and adherence to prescribed medication regimens $(4,5)$. Limited beneficial treatment outcomes, harmful side effects, and non-adherence are major problems in healthcare worldwide, linked with poor health outcomes and increasing healthcare costs $(1,6,7)$. Negative attitudes towards medication have been associated with the occurrence of negative medication (side) effects $(1,2)$ and, partially resulting from that, non-adherence (8). This association between negative attitudes toward medication and medication side effects may be explained by nocebo effects, as it also occurs in response to inert treatments (7). In addition to the lack of negative attitudes, positive attitudes towards medication may increase medication effectiveness $(3,7,9)$, akin to how positive outcome expectancies of a specific treatment can contribute to placebo effects $(8,10,11)$. Having a positive attitude towards medication in general, trusting the effectiveness of the medication, and being convinced that the treatment is needed, has also been associated with increased adherence $(4,5)$. Ultimately, fostering positive attitudes towards medications could help in optimizing the effects of pharmacotherapy and preventing nocebo-induced side effects and non-adherence $(7,12)$.

Despite these indications that both negative and positive attitudes towards medication are of importance, current research mainly focuses on the impact of negative attitudes towards and beliefs about medication $(1,2,7)$. This focus on negative attitudes is also reflected in the instruments currently available to asses attitudes towards medication (e.g. Beliefs about Medicines Questionnaire-General (13)). Other questionnaires, assessing positive as well as negative attitudes, are concerned with attitudes towards specific medication such as pain or anti-psychotic medication (Beliefs about Medicines Questionnaire-Specific; 13, Pain Medication Attitude Questionnaire; 14, 15; Drug Attitude Inventory-10; 16,17$)$ and are as such highly valuable in specific contexts but do not allow comparisons across diverse settings and samples.

To enable research into negative and positive attitudes of medication in a variety of settings and samples, a questionnaire that assesses negative as well as positive attitudes towards medication in general is needed. The current paper describes the development of such a questionnaire, the General Attitude towards Medication Questionnaire (GAMQ) and the evaluation of its psychometric properties in both healthy and patient samples (rheumatoid arthritis, RA, and atopic dermatitis, AD). Patients with RA and AD often experience chronic pain or itch for which many use medication for an extended period of time. Both pain and itch are known for their responsiveness to placebo and nocebo effects $(10,18,19)$, and thus might be specifically sensitive to beliefs and attitudes about medication. To evaluate the psychometric properties of the GAMQ, the stability of the factor structure across samples was tested (20) in two general and two patient samples. Furthermore, the internal consistency 
of the questionnaire, convergent validity (association with existing medication attitude questionnaire), predictive validity (association with expected effectiveness and side effects of medication), and associations with demographic and health-related characteristics were analyzed in each of the four samples. 


\section{Method}

\section{Respondents}

To ensure the availability of representative general samples and samples of patients with RA and $A D$, the GAMQ was administered as part of different questionnaire studies. For the validation of the GAMQ, data from these studies were combined. The specific methods used to recruit participants and collect data varied between studies. Also, the studies differed with regard to additional questionnaires that were assessed. See Table A.1. in the Supplemental Digital Content for an overview of the relevant questionnaires per sample. Data from a general sample (Gs1) (21) and samples of patients with Rheumatoid Arthritis (RAs) and Atopic Dermatitis (ADs) were obtained in a study investigating expectations about negative and positive effects of different routes of medication administration (in the RA patients sleep quality and the circadian rhythm were investigated as well). A second general sample (Gs2) was obtained from an online experimental and questionnaire study on imagery and the induction of pain medication outcome expectations by verbal suggestion. Both studies were approved by the relevant local ethics committee.

\section{General sample 1 (Gs1)}

A general sample that was representative of the adult Dutch population in terms of gender, age, and province of residence was recruited via an online service (Qualtrics, Provo, UT, USA) in September 2015. All respondents were asked to fill in a battery of online questionnaires, including the GAMQ, taking approximately 20 minutes.

\section{General sample 2 (Gs2)}

A second general sample that was representative of the Dutch population in terms of gender and age was recruited via posters and flyers at various public locations (e.g., library, gym, pharmacy), social media, participant recruitment websites, and personal networks in the Netherlands. Data collection took place from March to June 2016. Respondents filled in a battery of online questionnaires, including the GAMQ, taking approximately 35 minutes via Qualtrics.

\section{Rheumatoid arthritis sample (RAs)}

Patients with RA fulfilling the 1987 ACR criteria were recruited from the Leiden Early Arthritis Clinic (EAC) cohort (22), a population-based prospective cohort. Patients were approached via email and could choose whether they wanted to fill out the battery of questionnaires via Qualtrics or using paper and pencil. Data collection took place in October 2015. Filling out the questionnaires took approximately 45 minutes. 
General Attitude towards Medication Questionnaire

\section{Atopic Dermatitis sample (ADs)}

Patients with AD who visited the Department of Dermatology of the Leiden University Medical Center in the preceding year were approached via regular post from January to March 2016 . They could choose whether they wanted to fill out the battery of questionnaires via Qualtrics or using paper and pencil. Completing the questionnaires took participants around 30 minutes.

\section{General Attitude towards Medication Questionnaire (GAMQ)}

Respondents of all samples completed the General Attitudes towards Medication Questionnaire (GAMQ). To reflect both negative and positive attitudes towards medication, 6 positively and 6 negatively worded items were created. Items for the GAMQ were adapted from other questionnaires measuring attitudes towards and beliefs about medication or were newly developed. Questionnaires that provided inspiration for items were: the general and specific scales of the Beliefs about Medicines Questionnaire (BMQ, 13), the Pain Medication Attitude Questionnaire (PMAQ; 14), the Drug Attitude Inventory (DAI, 16, 17), and a study-specific attitude towards pain medication scale (15). Selection and adaptation of existing items and development of new items was done by authors $\mathrm{KP}$ and JT with assistance of $\mathrm{AE}, \mathrm{AvL}$, and MP. The goal was to select and create around 10 items that are easy to understand and clearly reflect a personal view ("I think..."). To create a balanced scale assessing negative as well as positive attitudes, an equal number of positive and negative items was included in the questionnaire. The introduction with instructions on how to fill in the GAMQ as well as the answering options were adapted from the BMQ-G (13). Participants are requested to rate each item on a 5-point Likert scale, ranging from 1 ("strongly disagree") to 5 ("strongly agree").

The GAMQ was formulated and tested in Dutch. The English version was obtained by forwardbackward translation. The initial forward translation form Dutch to English was done by a native speaker and certified translator in collaboration with the authors JT and KP. After consensus was achieved about the first English version, native Dutch author HvM, who was blinded for the original Dutch version, translated the first English version back to Dutch. Comparison of this backward translation to the original Dutch questionnaire and the first English translation by the translator and authors JT and KP led to minor adjustments in the final English translation provided in Table 1. For the Dutch version, please see Supplemental Digital Content Table A.2. 
Table 1. The English translation of the General Attitude towards Medication Questionnaire (GAMQ) including instruction and response options.

We want to ask you some questions about what you think about medication in general. We are interested in your views about medication that has been prescribed for you by your doctor. Please indicate to what extent you agree or disagree with the following statements. There are no right or wrong answers. We are interested in your views.

\begin{tabular}{|c|c|c|c|c|c|}
\hline & $\begin{array}{l}\text { Strongly } \\
\text { disagree }\end{array}$ & Disagree & Uncertain & Agree & $\begin{array}{l}\text { Strongly } \\
\text { agree }\end{array}$ \\
\hline $\begin{array}{l}\text { 1) I am concerned about the side } \\
\text { effects of medication. }\end{array}$ & 0 & 0 & & 0 & 0 \\
\hline $\begin{array}{l}\text { 2) I think that medication can help with } \\
\text { my symptoms. }\end{array}$ & 0 & 0 & & & O \\
\hline $\begin{array}{l}\text { 3) I am afraid that medication has a } \\
\text { harmful effect on my body. }\end{array}$ & ? & & & & 0 \\
\hline $\begin{array}{l}\text { 4) If I have symptoms, I readily take } \\
\text { medication for them. }\end{array}$ & & & & & O \\
\hline 5) I find it unnatural to take medication. & & & & 0 & 0 \\
\hline $\begin{array}{l}\text { 6) I trust that it is safe to take } \\
\text { medication. }\end{array}$ & & & & 0 & O \\
\hline $\begin{array}{l}\text { 7) I only take medication if there is } \\
\text { absolutely no other option. }\end{array}$ & & & & ○ & 0 \\
\hline $\begin{array}{l}\text { 8) I have no problem with taking } \\
\text { medication if I have symptoms. }\end{array}$ & & & & 0 & o \\
\hline $\begin{array}{l}\text { 9) I would rather endure my symp } \\
\text { than take medication. }\end{array}$ & & 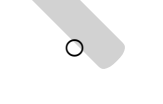 & 0 & 0 & 0 \\
\hline $\begin{array}{l}\text { 10) I trust in the effectiveness of } \\
\text { medication. } \\
\text { 11) I am afraid of becoming addicted if I }\end{array}$ & & 0 & 0 & O & ○ \\
\hline $\begin{array}{l}\text { take medication for an extended } \\
\text { period. }\end{array}$ & & 0 & 0 & o & ○ \\
\hline $\begin{array}{l}\text { 12) For me the advantages of } \\
\text { medication outweigh the } \\
\text { disadvantages. }\end{array}$ & 0 & 0 & O & O & O \\
\hline
\end{tabular}

\section{Materials and measures}

\section{General beliefs about medication}

Beliefs about medication in general were measured using the Beliefs about Medicines Questionnaire - General (BMQ-G, 13) in all of the investigated samples. The BMQ-G consists of two subscales, the General-Harm and the General-Overuse scales, measuring general beliefs about the harmfulness of medication (e.g., "All medicines are poisons") and doctor's over-prescription of medication (e.g., "Doctors use too many medicines"), respectively. Each of the scales consists of 4 items that are rated on a 5-point Likert scale, ranging from 1 ("strongly disagree") to 5 ("strongly agree"). Summing these items per scale results in scores ranging from 4 to 20, with higher scores 
reflecting more negative beliefs. Internal consistency as indicated by Cronbach's alpha for the GeneralHarm subscale ranged from $\alpha=.65$ (questionable) in RAs to $\alpha=.73$ (acceptable) in Gs1. For the GeneralOveruse subscale, Cronbach's alpha was acceptable in all samples, ranging from $\alpha=.71$ in ADs to $\alpha=.78$ in Gs1 and Gs2.

\section{Medication attitude visual analogue scale (VAS)}

Respondents of all samples were also asked to rate their general attitude towards medication ("How do you think about medication in general?") on a visual analogue scale (VAS) ranging from 0 ("very negatively") to 100 ("very positively").

\section{Expectations regarding medication}

Participants of the Gs1, RAs, and ADs rated their expectations about the effectiveness for pain and itch relief as well as about side effects of different routes of medication administration (oral, injection, and topical routes) on visual analogue scales ranging from 0 ("not at all") to 100 ("very much") (21). For the current study, VAS scores of the different routes of medication administration were averaged, resulting in three scores reflecting 1 ) the expected effectiveness of medication for pain relief, 2) the expected effectiveness of medication for itch relief, and 3) the expected side effects of medication.

\section{Demographic and health-related characteristics}

All respondents were asked to provide information about their age, gender, marital status, education level, religious affiliation, nationality, and fluency in Dutch language. Regarding healthrelated characteristics, respondents were asked whether they were currently undergoing treatment for any illness(es). Additionally, they were asked to rate the intensity of currently experienced pain or itch on a VAS ranging from 0 ("none at all") to 100 ("very much"). In the GS2, respondents only rated current pain intensity, on an 11-point numerical rating scale with identical anchors as the VAS.

Health-related quality of life was measured using the Short Form-12 (SF-12, 23) in the Gs1 and the Short Form-36 (SF-36) in the RAs and ADs. As the SF-36 contains all items included in the SF-12, responses on the SF-36 were used to compute the SF-12 scores. The SF-12 results in two scores, namely the physical health composite score (PCS), and the mental health composite score (MCS). The PCS consists of physical functioning, role limitations due to physical problems, bodily pain, and general health, and comprises items like "During the past 4 weeks, how much did pain interfere with your normal work (including work outside the home and housework)?". The MCS consists of mental health, role limitations due to emotional problems, social functioning, and vitality, and comprises items like "How much of the time during the past 4 weeks have you felt calm and peaceful?". Scores are 
calculated based on item response theory, with regression weights standardized for the Dutch population (23).

To assess disease activity and impact in the patient samples, the Disease Activity Score 44 (DAS44, 24) was used in the RAs, while the respondents in the ADs completed the Patient Oriented Eczema Measure (POEM, 25). The DAS-44 is a measure of disease activity in rheumatoid arthritis combining symptoms of tenderness and swelling in 44 joints with the Erythrocyte Sedimentation Rate in $\mathrm{mm} /$ hour and a general health assessment expressed on a visual analogue scale ranging from 0 to 100. The DAS-44 scores of respondents in the RAs were determined during their last visit at the LUMC (approximately 24 weeks prior to filling in the questionnaire) which were made available for use in this study from the Leiden EAC Cohort (22). High scores on the DAS-44 reflect more disease activity, with scores below 1.6 indicating clinical remission. Cut off points for disease activity are low $(\leq 2.4)$, moderate (>2.4 to 3.7), and high (>3.7) (26). The POEM was used to measure eczema severity in the ADs. It comprises seven items assessing on how many days of the past week the patient experienced 7 different symptoms of eczema. Each item is rated from 0 ("no days") to 4 ("every day"), resulting in a minimum score of 0 and a maximum score of 28 , with higher scores indicating more severe eczema. Additionally, scores are banded into categories as follows: 0 to 2 clear or almost clear from eczema, 3 to 7 mild eczema, 8 to 16 moderate eczema, 17 to 24 severe eczema, and 25 to 28 very severe eczema. Internal consistency of the POEM in the current study was good $(\alpha=.89)$.

\section{Quality of the responses}

The questionnaire sets for each sample contained items included to ensure the quality of the responses. For all samples, the questionnaire sets concluded with two items inquiring whether respondents were able to understand the questions asked in the questionnaire and whether respondents had read all questions well before answering. The questionnaire sets for both general samples included two additional control questions on which respondents were requested to give a pre-defined answer, to check whether they read the questions well.

\section{Statistical analyses}

Descriptive statistics, univariate analyses of variance (ANOVAs), chi-square tests, and Pearson correlations were calculated using SPSS version 25 (IBM Corporation, Armonk, NY, USA). Factor analyses were run using the Latent Variable Analysis software package (lavaan 0.6-3) in R (version 3.4.3). The significance level for all tests was set at $\alpha=.05$ (two-tailed). For correlations, cut-off values of $r=.10, .30$, and .50 were used to indicate small, medium, and large correlations, respectively (27). For ANOVAs, partial eta squared $\left(\eta_{p}{ }^{2}\right)$ was calculated as an indicator of the effect size. Cut off values of $\eta_{\mathrm{p}}{ }^{2}=.01, .06$, and .14 were used to indicate small, medium, and large effects, respectively (27). All 
General Attitude towards Medication Questionnaire

correlations and ANOVAs, including post-hoc tests, were tested for significance using simple bootstrap with 1000 samples and the bias corrected accelerator.

Between-sample differences in medication attitude scores, as well as demographic and healthrelated characteristics were analyzed using univariate ANOVAs for continuous variables and chi-square tests for categorical variables.

The factor structure of the newly developed GAMQ was investigated in all samples using the following procedure $(20,28,29)$ : First, an exploratory principal component analysis (PCA) using varimax rotation was run in a random subsample consisting of $60 \%$ of Gs1 (training sample, $n=305$ ) to inform on the general component structure of the GAMQ. Next, the resulting structure was tested by a confirmatory factor analysis (CFA) in the same training sample with bootstrap (1000 draws), to obtain robust standard error estimates. This was repeated in the remaining $40 \%$ of Gs1 ( $n=203$ ). The generalizability of this factor structure was investigated by CFA, using 1000 bootstrap draws, in Gs2, and the RAs and ADs. As measures of fit, the Comparative Fit Index (CFI)(30, 31) for which $\geq .90$ indicates adequate fit and $\geq .95$ indicates excellent fit, as well as the Root Mean Square Error of Approximation (RMSEA; 32) and the Standardized Root Means Square Residual (SRMSR; 33) for both of which $\leq .08$ indicates adequate fit and $\leq .05$ indicates excellent fit (34), were calculated in each sample. Finally, the stability of the factor structure (measurement invariance) across the samples was tested using 5 different, progressively restrictive, models: 1) factor configuration, 2) factor loadings, 3) intercepts, 4) residuals, and 5) means (20).

As an indicator for internal consistency of the GAMQ, Cronbach's $\alpha$ was computed for the questionnaire as a whole and for all subscales identified by the factor analysis. Cut-off values for Cronbach's $\alpha$ were $\leq .50$ : unacceptable, .50-.60: poor, .60-.70: questionable, .70-.80: acceptable, .80.90: good, and $\alpha \geq .90$ : excellent (35). Also, Cronbach's $\alpha$ if each individual item is omitted was reported for the GAMQ total and subscale scores. Furthermore, the distribution of scores and use of each item of the GAMQ was described. As indicators of convergent validity, correlations of the GAMQ total and subscale scores with the BMQ-G General-Harm and General-Overuse subscales and with respondent's medication attitude VAS score were calculated. To explore possible predictive validity of the GAMQ, associations with expected medication effects were analyzed. Finally, correlations of the GAMQ total and subscales with demographic and health variables were calculated. 


\section{Results}

\section{Sample characteristics}

\section{General sample 1 (Gs1)}

Nine hundred four respondents reacted to the invitation for study participation. Of these, 112 (12\%) never started filling out the questionnaires, 234 (26\%) stopped filling out the questionnaires prematurely or were automatically excluded for failing to give the requested answer to one of the control questions. The remaining 558 (62\%) filled out the questionnaires completely. Of these, two $(<1 \%)$ indicated that they were not able to speak Dutch fluently and $40(7 \%)$ respondents were over quota regarding gender, age, or province of residence. Five (1\%) respondents completed the questionnaires in less than $1 / 3$ of the median time (i.e. in under $6.4 \mathrm{~min}$ ) and another three $(<1 \%)$ indicated not having read or understood the questions well. These respondents were excluded, resulting in 508 (56\% of the initial 904) respondents included in this study.

\section{General sample 2 (Gs2)}

In total, 690 respondents initiated participation in the study. Of these, nine (1\%) respondents explicitly refused informed consent and 296 (43\%) completed the questionnaires. Of those who completed the questionnaires, nine (3\%) answered one or both of the control questions incorrectly and one $(<1 \%)$ respondent did not speak Dutch fluently. Five $(2 \%)$ respondents completed the questionnaires in less than $1 / 3$ of the median time $(<11 \mathrm{~min})$. One $(<1 \%)$ respondent indicated not having understood the questions well and one $(<1 \%)$ did not give up his or her age, making it impossible to determine if the respondent was at least 18 years old (inclusion criterion). All these respondents were excluded, resulting in a total of 279 (40\% of the initial 690 ) respondents.

\section{Rheumatoid arthritis sample (RAs)}

Of the 305 invited patients, 145 (48\%) responded by filling out the questionnaires at least partially. Ninety-five (66\%) of these respondents opted to fill out the questionnaires via an online service, while 50 (34\%) filled out a paper and pencil version of the questionnaires and returned it via postal service. Of these 145 respondents, seven (5\%) respondents explicitly refused to consent and ended participation. Eight (6\%) respondents did not fill out the informed consent form, but since they filled out the questionnaires and took the effort to return them via postal service, consent was inferred. Of the remaining respondents, 126 (91\%) filled out the GAMQ completely, making the response useful for this study. Of these, one $(<1 \%)$ respondent indicated not being able to speak Dutch fluently and four (3\%) did not indicate having understood or read the questions well. The remaining 121 (40\% of the invited 305) respondents were included in this study. 
General Attitude towards Medication Questionnaire

\section{Atopic Dermatitis sample (ADs)}

Of the 300 invited respondents $79(26 \%)$ filled out the questionnaires at least partially. Of these, 35 (44\%) respondents opted to fill out the questionnaires via an online service, while 44 (56\%) filled out and returned a paper and pencil version of the questionnaires. Five respondents (6\%) explicitly refused informed consent. Two (3\%) respondents did not fill out the informed consent form but completed and returned the questionnaires. Again, this was interpreted as informed consent to participate in the study. Of the remaining respondents, 71 (96\%) filled out the GAMQ completely. All of these respondents indicated to be fluent Dutch speakers. One respondent (1\%) who failed to indicate whether he or she had understood and read the questions well was excluded. The remaining $70(23 \%$ of the invited 300$)$ respondents were included in this study.

\section{Sample comparisons demographic and health-related characteristics}

See Table A.3 in the Supplemental Digital Content for an overview of the demographic and health-related characteristics per sample, including comparisons between the samples. Notable differences in demographic characteristics were: 1 ) the relatively older age of respondents in the RAs; 2) the larger proportion of women in the RAs; 3 ) the relatively high education level in especially the Gs2, but also the ADs; 4) the relatively high number of respondents who had no religious or ideological affiliation in the Gs2, particularly in comparison to the patient samples; and 5) the somewhat higher proportion of respondents in a relationship in the RAs.

Concerning health-related characteristics, notable differences were: 1) a relatively small proportion of the respondents in Gs2 was in treatment for long-lasting physical or mental complaints; 2) physical health-related quality of life was somewhat lower in the RAs than in the ADs and Gs1; while mental health-related quality of life did not significantly differ between the samples; 3) as can be expected, current pain was higher in the RAs than all other samples; 4) likewise, current itch was notably higher in the ADs than in the Gs1 and the RAs. Furthermore, mean disease activity (DAS-44) in the RAs was close to clinical remission. In the ADs, POEM scores indicated the mean eczema severity to be moderate. Last, there were no substantial differences between expected effectiveness and expected side effects of medication between the samples.

\section{GAMQ Factor structure and measurement invariance}

An exploratory principal component analysis on $60 \%$ of the Gs1 suggested that the GAMQ consists of 3 underlying components; one component comprises items 2, 6, 8, 10, and 12 which represent Trust in medication (i.e., Trust; Eigenvalue $=3.06$ ), the second consists of items 1,3 , and 11 which represent Concerns about medication (i.e., Concerns; Eigenvalue $=2.12$ ), and the third contains items 5, 7, and 9 which represent Reluctance to use medication (i.e., Reluctance; Eigenvalue $=2.10$ ). 
Taken together, these three components explained $61 \%$ of the variance. The loadings of item 4 stayed below the threshold of 0.35 for all of the three components and was left out of the subsequent factor analyses, but kept in the total scale. Stricter evaluation using confirmatory factor analysis (CFA) confirmed the suggested 3-component structure in the $60 \%$ training sample as well as in the $40 \%$ validation set. The estimated standardized factor loadings obtained by CFA with bootstrap in the same $60 \%$ of Gs1, the remaining $40 \%$ of Gs1, Gs1 as a whole, Gs2, RAs, and ADs are presented in Table 2.

The CFI suggests an adequate fit of the factor structure for the ADs and Gs1 and a close to adequate fit in the other samples. The RMSEA, where smaller values indicate a better fit, was close to .08 in all samples, indicating a close to adequate fit. The SRMSR, which has the same cut-off values as the RMSEA, indicated an adequate fit (Table 2). Taken together, and considering the highly differential nature of the samples, the fit of the factor structure was deemed adequate for all samples.

Table 2. Items of the GAMQ with factor loadings derived from confirmatory factor analyses and estimates of fit for the factor model per sample.

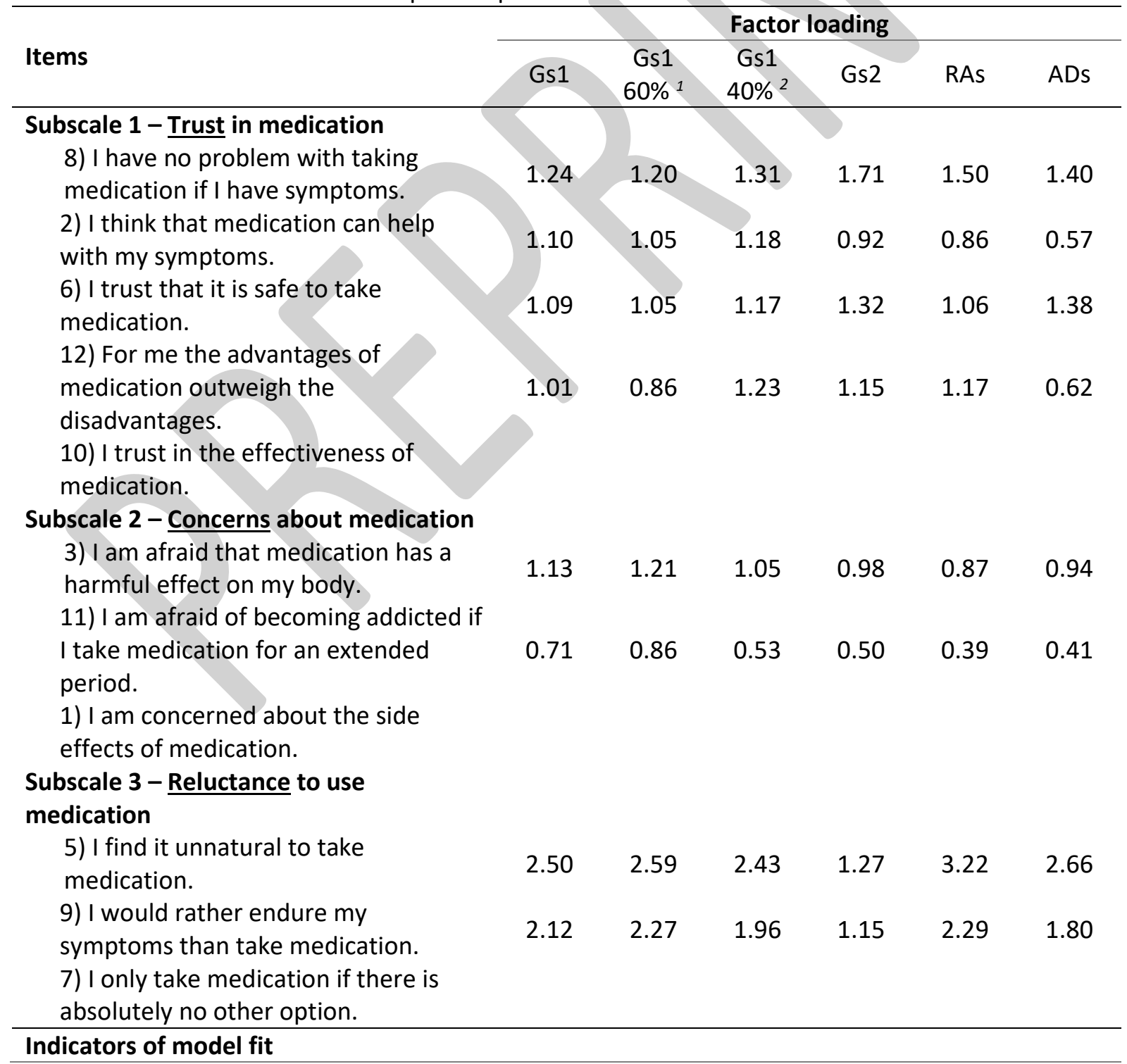




\begin{tabular}{lllllll}
\hline CFI & .91 & - & .87 & .89 & .84 & .90 \\
RMSEA & .09 & - & .12 & .09 & .10 & .09 \\
SRMSR & .06 & - & .07 & .05 & .07 & .08 \\
\hline
\end{tabular}

Note. ${ }^{1}$ CFA in training sample. ${ }^{2}$ CFA in remaining $40 \%$ of Gs1. Gs1: General sample 1, Gs2: General sample 2, RAs: Rheumatoid Arthritis sample, ADs: Atopic dermatitis sample CFI: Comparative Fit Index, RMSEA: Root Mean Square Error of Approximation, SRMSR: Standardized Root Means Square Residual.

The measurement invariance tests across the samples for the proposed factor structure of the GAMQ (Table 3) indicated that the overall fit of the proposed factor structure (Model 1 ) is adequate $(\mathrm{CFI}=.90)$ or close to adequate (RMSEA $=.09)$ and thus stable across samples. Adding more constraints to this model such as the loadings, intercept and residuals significantly decreased the fit indicated by the CFI (Models 2 to 5), indicating that theses parameters differ across samples.

Table 3. Fit statistics testing the measurement invariance of the proposed factor structure across all samples.

\begin{tabular}{|c|c|c|c|c|c|c|c|}
\hline \multicolumn{2}{|c|}{ Model } & \multirow{2}{*}{$\frac{\chi^{2}}{495.60}$} & \multirow{2}{*}{$\frac{D f}{164}$} & \multirow{2}{*}{$\begin{array}{l}\text { CFI } \\
.90\end{array}$} & \multirow{2}{*}{$\begin{array}{c}\text { RMSEA } \\
.09\end{array}$} & \multirow{2}{*}{$\Delta x^{2 *}$} & \multirow[t]{2}{*}{$\Delta d f$} \\
\hline 1) & Factor configuration invariant & & & & & & \\
\hline 2) & as above $\&$ loadings invariant & 552.49 & 188 & .89 & .09 & 56.89 & 24 \\
\hline 3) & all of the above \& intercept invariant & 646.13 & 212 & .87 & .09 & 93.64 & 24 \\
\hline 4) & all of the above \& residuals invariant & 730.67 & 245 & .85 & .09 & 84.54 & 33 \\
\hline 5) & all of the above \& means invariant & 762.92 & 254 & .85 & .09 & 32.25 & 9 \\
\hline
\end{tabular}

Note. ${ }^{*}$ All $\Delta \chi^{2}$ significant at $p<.001 . \chi^{2}$ : Satorra-Bentler scaled statistic, CFI: Comparative Fit Index, RMSEA: Root Mean Square Error of Approximation.

\section{Scoring of the GAMQ, frequency distribution of scores, and use of each item}

To obtain the total score for the GAMQ, scores on the negatively worded items (items 1, 3, 5, $7,9,11)$ were reversed and the sum-score of all items was calculated. This resulted in scores with a theoretical minimum of 12 and maximum of 60 . As the individual subscales determined during factor analysis (see below) contain either only positively or only negatively worded items, sum-scores were calculated and items were not reversed. Visual inspection of histograms indicated that the distribution of scores for the GAMQ total, and subscales was close to normal in all samples. Generally, the distribution of the total and subscale scores covered the full or almost full theoretical range. Frequency distribution of scores for each item indicated that for most items all answering categories were used in all samples. In case a response option was not used, this favored a more positive attitude towards medication.

\section{Internal consistency GAMQ}

Internal consistency of the GAMQ total scale, as indicated by Cronbach's alpha is displayed in Table 4. Cronbach's alpha was generally good for the total scale, but lower for the subscales, particularly Concerns and Reluctance, which included a smaller number of items. Cronbach's alpha if each separate item is omitted is reported in Supplemental Digital Content Table A.4 to A.7. For the total scale and subscales Trust and Reluctance no item stood out as significantly affecting the internal 
consistency. For the subscale Concerns, omitting item 11 ("I am afraid of becoming addicted if I take medication for an extended period") would increase Cronbach's alpha. However, considering its content and fit in the total scale, item 11 was kept in the questionnaire.

Table 4. Cronbach's alpha as indicator of internal consistency for the GAMQ total and subscale scores for each sample

\begin{tabular}{lcccc}
\hline Scale & \multicolumn{4}{c}{ Cronbach's alpha } \\
& Gs1 & Gs2 & RAs & ADs \\
\hline GAMQ Total & .84 & .83 & .78 & .81 \\
GAMQ Trust & .81 & .78 & .73 & .74 \\
GAMQ Concerns & .69 & .59 & .67 & .71 \\
GAMQ Reluctance & .67 & .67 & .56 & .66 \\
\hline
\end{tabular}

Note. Gs1: General sample 1, Gs2: General sample 2, RAs: Rheumatoid Arthritis sample, ADs: Atopic dermatitis sample.

\section{Sample comparisons on medication attitude}

See Table 5 for an overview of the medication attitude scores per sample. Comparisons of the samples on the GAMQ total and subscale scores, the BMQ subscale scores for Harm and Overuse and medication attitude VAS scores showed only minimal differences between the samples. On the GAMQ total score and subscale Trust, the Gs2 scored slightly lower than the other samples (total $p<.05$, Trust p<.01), which did not differ from each other. On the BMQ-G subscale Harm, the ADs scored slightly lower than all other samples $(p<.05)$, while the Gs2 scored slightly lower than Gs1 $(p=.001)$. On the General-Overuse subscale, Gs1 scored significantly higher than the Gs2 ( $p<.05)$, RAs, and ADs $(p<.01)$; RAs and ADs scored significantly lower than Gs2 but did not significantly differ from each other. On medication attitude VAS scores Gs2 scored slightly lower than Gs1 ( $<<.01)$.

Table 5. Medication attitude for each sample - mean (SD)

\begin{tabular}{lccccc}
\hline & Gs1 & Gs2 & RAs & ADs & Sample comparisons \\
& $(n=508)$ & $(n=279)$ & $(n=121)$ & $(n=70)$ & \\
\hline GAMQ Total & 39.83 & 38.10 & 39.86 & 40.37 & $\mathrm{~F}(3,974)=4.53$, \\
GAMQ Trust & $(7.01)$ & $(7.23)$ & $(6.23)$ & $(6.73)$ & $\mathrm{p}=.004, \eta_{\mathrm{p}}{ }^{2}=.01$ \\
& 18.74 & 17.90 & 19.16 & 19.09 & $\mathrm{~F}(3,974)=6.75$, \\
GAMQ Concerns & $(3.15)$ & $(3.29)$ & $(2.85)$ & $(3.01)$ & $\mathrm{p}<.001, \eta_{\mathrm{p}}{ }^{2}=.02$ \\
& 8.76 & 9.08 & 9.11 & 8.74 & $\mathrm{~F}(3,974)=1.38$, \\
GAMQ Reluctance & $(2.52)$ & $(2.42)$ & $(2.48)$ & $(2.59)$ & $\mathrm{p}=.246, \eta_{\mathrm{p}}{ }^{2}=.00$ \\
& 8.85 & 9.23 & 8.83 & 8.71 & $\mathrm{~F}(3,974)=1.94$, \\
BMQ-G General-Harm & $(2.32)$ & $(2.44)$ & $(2.23)$ & $(2.38)$ & $\mathrm{p}=.121, \eta_{\mathrm{p}}{ }^{2}=.01$ \\
& 10.60 & 9.90 & 10.21 & 9.01 & $\mathrm{~F}(3,968)=9.33$ \\
BMQ-G General-Overuse & $(2.74)$ & $(2.62)$ & $(2.45)$ & $(2.66)$ & $\mathrm{p}<.001, \eta_{\mathrm{p}}{ }^{2}=.03$ \\
& 12.51 & 12.03 & 11.39 & 11.21 & $\mathrm{~F}(3,970)=7.28$, \\
Medication attitude VAS & $(3.00)$ & $(3.13)$ & $(2.68)$ & $(3.01)$ & $\mathrm{p}<.001, \eta_{\mathrm{p}}{ }^{2}=.02$ \\
& 63.55 & 58.58 & 63.76 & 63.34 & $\mathrm{~F}(3,949)=3.07$, \\
& $(23.62)$ & $(22.72)$ & $(23.38)$ & $(19.59)$ & $\mathrm{p}=.027, \eta_{\mathrm{p}}{ }^{2}=.01$ \\
\hline
\end{tabular}

Note: Gs1: General sample 1, Gs2: General sample 2, RAs: Rheumatoid Arthritis sample, ADs: Atopic dermatitis sample. BMQ-G: general scale of the Beliefs about Medicines Questionnaire, VAS: visual analogue scale, GAMQ: General Attitude towards Medication Questionnaire. 


\section{Convergent validity: Associations of the GAMQ with measures of medication attitude}

Convergent validity of the GAMQ was tested by investigating the associations of the GAMQ total and subscale scores with the BMQ-G General-Harm and General-Overuse scores and the medication attitude VAS. As visible in Table 6, a more positive general medication attitude according to the GAMQ Total consistently showed strong negative correlations with the BMQ-G subscales and correlated positively and strongly with a more positive medication attitude VAS score across samples. The positive GAMQ subscale Trust consistently correlated negatively with the BMQ-G subscale scores and positively with the medication attitude VAS score. The negative GAMQ subscales Concerns and Reluctance were positively correlated with both BMQ-G subscale scores and negatively correlated with the medication attitude VAS score in all samples. Most of these correlations were moderate to strong in all samples.

The GAMQ total correlated strongly with all of its subscales. As can be expected, correlations with Trust were positive, while correlations with Concerns and Reluctance were negative. The subscale Trust showed negative correlations with Concerns. This association was moderate in the general samples and weak in the patient samples. Trust also correlated strongly and negatively with Reluctance, except in the RAs where this association was moderate. Subscales Concerns and Reluctance correlated moderately and positively with each other in all samples. 
General Attitude towards Medication Questionnaire

Table 6. Associations of the GAMQ with other indicators of beliefs about or attitudes towards medication and its own subscales.

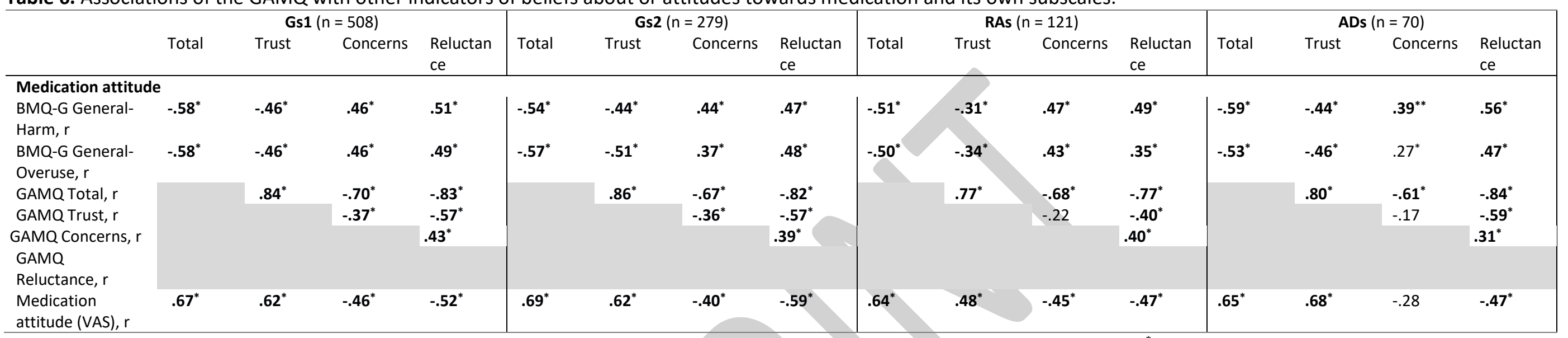

Note: Gs1: General sample 1, Gs2: General sample 2, RAs: Rheumatoid Arthritis sample, ADs: Atopic dermatitis sample. n.a. = data not available; ${ }^{*}$ bootstrapped confidence intervals did not include 0. ${ }^{1}$ In treatment for long-lasting medical or psychological complaints or diseases other than Ra for RAs and AD for ADs. SF12 PCS: Short Form 12 Physical Component Score, SF-12

MCS: Short Form 12 Mental Component Score, DAS44: Disease Activity Score, POEM: Patient Oriented Eczema Measure, BMQ-G: general scale of the Beliefs about Medicines Questionnaire,

VAS: visual analogue scale, GAMQ: General Attitude towards Medication Questionnaire. Medium and large effect sizes are printed in bold. 


\section{Predictive validity: Associations of the GAMQ with expected medication} effects

All associations of the GAMQ total and subscale scores with expected medication effects can be found in the Supplemental Digital Content (Table A.8.) and only statistically significant, moderate associations are reported here. Expected effectiveness of medication for pain was positively associated with the GAMQ Total in the RAs and with the subscale Trust in the Gs1. Expected effectiveness of medication for itch was positively associated with the GAMQ Total and the subscale Trust in the ADs. Expected side effects were negatively correlated with the GAMQ Total and the subscale Trust, and positively associated with the subscale Reluctance in the ADs.

\section{Associations between the GAMQ and demographic and health variables}

All associations of the GAMQ total and subscale scores with demographic and health variables can be found in the Supplemental Digital Content (Table A.8.). Only statistically significant, moderate associations are reported here. Religious or ideological affiliation was moderately associated with the GAMQ Total in the RAs. Respondents who were not affiliated with any religion or who identified as Christian had a more positive attitude towards medication than respondents affiliated with other religions. Religious or ideological affiliation was also moderately associated with the GAMQ subscale Trust in the RAs, however post-hoc pairwise comparisons between the different affiliations were statistically non-significant. Concerning health, in the ADs, respondents who had comorbidities scored moderately higher on the subscale Trust. 


\section{Discussion}

Attitudes towards medication are important predictors of treatment outcome and adherence (1-5). Current research and measures mainly focus on negative attitudes towards medication which may be involved in nocebo effects and affect treatment outcomes and adherence negatively $(1,2,7$, $8,13)$. Positive attitudes toward medication, however, may increase medication effectiveness $(3,7,9)$ and adherence $(4,5)$ partially through mechanisms that are also involved in placebo and nocebo effects. To facilitate research into the effects of both positive and negative attitudes towards medication in general, the General Attitude towards Medication Questionnaire (GAMQ) was developed and its psychometric properties were investigated in two general and two patient samples (rheumatoid arthritis, RAs, and atopic dermatitis, ADs).

The results of our study show that the GAMQ has satisfactory psychometric properties in terms of stability across the investigated samples, internal consistency, and convergent as well as predictive validity. Therefore, it is suggested to be suitable for assessing general medication attitudes, both negative and positive, in a wide variety of research settings and in various patient populations. The balanced nature of the GAMQ, and brevity render it a promising tool for investigating predictors of medication outcomes and adherence, as well as placebo and nocebo effects.

Exploratory and subsequent confirmatory factor analyses indicated that the GAMQ comprises three subscales that were named Trust in medication (i.e., Trust), Concerns about negative effects of medication (i.e., Concerns), and Reluctance to use medication (i.e., Reluctance). One item (item 4) could not be included in any of the subscales but was left in the total scale considering its content and its contribution to the internal consistency. Another item (item 11) affected the internal consistency of the subscale Concerns but was left in the scale as it addresses the topic of addiction to medication, which is deemed highly relevant for this questionnaire. The adequate, or close to adequate, fit of the factor structure in all four samples and the measurement invariance tests indicate that the GAMQ measures the same underlying construct in both general and patient populations (20). This consistency of the GAMQ factor structure across samples is not due to a lack of diversity of the investigated samples, as they differed with regard to important demographic factors (e.g., age, gender, and education) as well as health variables (chronic medical complaints, physical health-related quality of life, current pain and itch) and medication attitude (BMQ-G and GAMQ), although the latter differences were small. The internal consistency of the GAMQ total scale was generally good, and that of the Trust subscale was generally acceptable. The subscales Concerns and Reluctance, however showed relatively low internal consistency, which is probably due to the limited number of items contained in these subscales. However, taking into account the stability of the GAMQ's factor structure including these 
subscales, the subscale scores convey important information about specific aspects of general medication attitudes in addition to the total score.

Convergent validity of the GAMQ total scale and subscales was good, as indicated by the strength and direction of associations with the BMQ-G and a single item measure of medication attitude in all samples. This demonstrates the suitability of the GAMQ to measure general positive attitudes towards medication in addition to negative ones. Predictive validity of the GAMQ was investigated by examining its association with expectations about effectiveness of medication for pain and itch relief and expected side effects of medication. Overall, a positive attitude toward medication, seemed to be stronger and more consistently associated with expected effectiveness and side effects of medication than a negative attitude toward medication. This provides indications for the additional value of measuring general positive attitudes to medication. It may also hint towards a possible link between positive attitudes toward medication and expectancy induced placebo and nocebo effects. Notably, associations of the GAMQ total and subscale scores with expected effectiveness of medication for pain were mostly stronger than for itch in the RA sample including many respondents who were experienced with taking pain medication, while the opposite was true for the AD sample including many respondents who were experienced with taking medication against itch. These findings suggest that the GAMQ total score might also be informative in predicting people's medication-specific expectations, although further research is required to confirm this. Furthermore, GAMQ was not consistently or strongly associated with demographic or health related characteristics, but correlations that were found (i.e., associations with religious or ideological affiliation, with the presence of a (comorbid) illness, and quality of life in some samples) were largely consistent with research on other measures of general medication attitudes such as the BMQ-G (36-40).

The GAMQ was developed and validated in Dutch, and an English version of the questionnaire, obtained by forward-backward translation with the help of a certified translator and native speaker, is provided in this article. As other questionnaires assessing general medication attitudes are valid across different languages and cultural backgrounds (e.g. 41, 42-45), the same could be expected for the GAMQ. However, further research is needed to confirm this. The sample sizes of the patient samples were small for validation purposes. However, including the patient samples allowed for the GAMQ to be investigated in four distinct populations which differed from each other in important demographic and health characteristics and thus yielded valuable information about the usability of the GAMQ across diverse samples and generalizability of the results. Furthermore, the brevity of the GAMQ (12 items) enables its use in patient populations in which more lengthy questionnaires would be too tiring. Moreover, the balance between positive and negative items and their wording, clearly reflecting a personal view rather than a general truth, make it suitable for use in cross-sectional as well as experimental research and possibly clinical practice. Especially when it is important not to bias the 
responses of the participants by overly extreme and one-sided items and when general positive attitudes toward medication are equally as important as negative ones, as is the case in placebo and nocebo research, the GAMQ can be considered a suitable instrument. To conclude, the newly developed GAMQ is a sufficiently reliable and valid measure of positive and negative attitudes towards medication in general, and suitable for use in general and clinical populations. 


\section{References}

1. Heller MK, Chapman SC, Horne R. Beliefs about medication predict the misattribution of a common symptom as a medication side effect--Evidence from an analogue online study. J Psychosom Res. 2015;79:519-29.

2. Nestoriuc Y, Orav EJ, Liang MH, Horne R, Barsky AJ. Prediction of nonspecific side effects in rheumatoid arthritis patients by beliefs about medicines. Arthritis Care Res. 2010;62:791-9.

3. Watkinson A, Chapman SCE, Horne R. Beliefs About Pharmaceutical Medicines and Natural Remedies Explain Individual Variation in Placebo Analgesia. J Pain. 2017;18:908-22.

4. Horne R, Weinman J. Patients' beliefs about prescribed medicines and their role in adherence to treatment in chronic physical illness. J Psychosom Res. 1999;47:555-67.

5. Thorneloe RJ, Griffiths CEM, Emsley R, Ashcroft DM, Cordingley L. Intentional and Unintentional Medication Non-Adherence in Psoriasis: The Role of Patients' Medication Beliefs and Habit Strength. J Invest Dermatol. 2018;138:785-94.

6. WHO WHO. Adherence to Long-term Therapies: Evidence for Action. Geneva, Switzerland: 2003.

7. Webster RK, Weinman J, Rubin GJ. Medicine-related beliefs predict attribution of symptoms to a sham medicine: A prospective study. Br J Health Psychol. 2018;23:436-54.

8. Ammassari A, Murri R, Pezzotti P, Trotta MP, Ravasio L, De Longis P, Lo Caputo S, Narciso P, Pauluzzi S, Carosi G, Nappa S, Piano P, Izzo CM, Lichtner M, Rezza G, Monforte A, Ippolito G, d'Arminio Moroni M, Wu AW, Antinori A. Self-reported symptoms and medication side effects influence adherence to highly active antiretroviral therapy in persons with HIV infection. J Acquir Immune Defic Syndr. 2001;28:445-9.

9. MacKrill K, Petrie KJ. What is associated with increased side effects and lower perceived efficacy following switching to a generic medicine? A New Zealand cross-sectional patient survey. BMJ Open. 2018;8:2018-023667.

10. Petersen GL, Finnerup NB, Colloca L, Amanzio M, Price DD, Jensen TS, Vase L. The magnitude of nocebo effects in pain: a meta-analysis. Pain. 2014;155:1426-34.

11. Vase L, Petersen GL, Riley JL, 3rd, Price DD. Factors contributing to large analgesic effects in placebo mechanism studies conducted between 2002 and 2007. Pain. 2009;145:36-44.

12. Conn VS, Ruppar TM. Medication adherence outcomes of 771 intervention trials: Systematic review and meta-analysis. Prev Med. [Review]. 2017;99:269-76.

13. Horne R, Weinman J, Hankins M. The beliefs about medicines questionnaire: The development and evaluation of a new method for assessing the cognitive representation of medication. Psychology \& Health. 1999;14:1-24.

14. McCracken LM, Hoskins J, Eccleston C. Concerns about medication and medication use in chronic pain. J Pain. 2006;7:726-34.

15. Kamping S, Müller M, Klinger R, Schmitz J, Flor H. Analgesics in Chronic Back Pain. Zeitschrift für Psychologie. 2014;222:179-85.

16. Hogan TP, Awad AG, Eastwood R. A self-report scale predictive of drug compliance in schizophrenics: reliability and discriminative validity. Psychol Med. 1983;13:177-83.

17. Nielsen RE, Lindstrom E, Nielsen J, Levander S. DAI-10 is as good as DAI-30 in schizophrenia. European neuropsychopharmacology : the journal of the European College of Neuropsychopharmacology. 2012;22:747-50.

18. Peerdeman KJ, van Laarhoven Al, Keij SM, Vase L, Rovers MM, Peters ML, Evers AW. Relieving patients' pain with expectation interventions: a meta-analysis. Pain. 2016;157:1179-91.

19. van Laarhoven AIM, van der Sman-Mauriks IM, Donders ART, Pronk MC, van de Kerkhof PCM, Evers AWM. Placebo effects on itch: a meta-analysis of clinical trials of patients with dermatological conditions. J Invest Dermatol. 2015;135:1234-43.

20. Wang M-T, Willett JB, Eccles JS. The Assessment of School Engagement: Examining Dimensionality and Measurement Invariance by Gender and Race/Ethnicity. Journal of School Psychology. 2011;49:465-80. 
21. Peerdeman KJ, Tekampe J, van Laarhoven AIM, van Middendorp H, Rippe RCA, Peters ML, Evers AWM. Expectations about the effectiveness of pain- and itch-relieving medication administered via different routes. Eur J Pain. 2018;22:774-83.

22. de Rooy DP, van der Linden MP, Knevel R, Huizinga TW, van der Helm-van Mil AH. Predicting arthritis outcomes--what can be learned from the Leiden Early Arthritis Clinic? Rheumatology. 2011;50:93-100.

23. Mols F, Pelle AJ, Kupper N. Normative data of the SF-12 health survey with validation using postmyocardial infarction patients in the Dutch population. Quality of life research : an international journal of quality of life aspects of treatment, care and rehabilitation. 2009;18:403-14.

24. van Riel PL, Renskers L. The Disease Activity Score (DAS) and the Disease Activity Score using 28 joint counts (DAS28) in the management of rheumatoid arthritis. Clin Exp Rheumatol. 2016;34:S40-S4.

25. Charman CR, Venn AJ, Williams HC. The patient-oriented eczema measure: development and initial validation of a new tool for measuring atopic eczema severity from the patients' perspective. Archives of dermatology. 2004;140:1513-9.

26. Fransen J, van Riel PL. The Disease Activity Score and the EULAR response criteria. Clin Exp Rheumatol. 2005;23:S93-9.

27. Cohen J. Statistical power analysis for the behavioral sciences. Hillsdale, N.J.: L. Erlbaum Associates; 1988.

28. Widaman KF, Reise SP. Exploring the measurement invariance of psychological instruments: Applications in the substance use domain: American Psychological Association; 1997.

29. Meredith W. Measurement invariance, factor analysis and factorial invariance. Psychometrika. 1993;58:525-43.

30. Bentler PM. Comparative fit indexes in structural models. Psychol Bull. 1990;107:238-46.

31. Hu LT, Bentler PM. Cutoff criteria for fit indexes in covariance structure analysis: Conventional criteria versus new alternatives. Structural Equation Modeling: A Multidisciplinary Journal. 1999;6:1-55.

32. Steiger JH. Structural Model Evaluation and Modification: An Interval Estimation Approach. Multivariate Behavioral Research. 1990;25:173-80.

33. Hu L-T, Bentler PM. Fit Indices in Covariance Structure Modeling: Sensitivity to Underparameterized Model Misspecification. Psychological Methods. 1998;3:424-53.

34. Kline RB. Principles and Practice of Structural Equation Modeling, Fourth Edition: New York: Guilford Publications; 2015.

35. Cronbach $\amalg$. Coefficient alpha and the internal structure of tests. Psychometrika. [journal article]. 1951;16:297-334.

36. Koster ES, Heerdink ER, de Vries TW, Bouvy ML. Attitudes towards medication use in a general population of adolescents. European journal of pediatrics. 2014;173:483-8.

37. Horne R, Graupner L, Frost S, Weinman J, Wright SM, Hankins M. Medicine in a multi-cultural society: the effect of cultural background on beliefs about medications. Social science \& medicine (1982). 2004;59:1307-13.

38. Drangsholt SH, Cappelen UW, von der Lippe N, Hoieggen A, Os I, Brekke FB. Beliefs about medicines in dialysis patients and after renal transplantation. Hemodialysis international International Symposium on Home Hemodialysis. 2019;23:117-25.

39. Kumar K, Gordon C, Toescu V, Buckley CD, Horne R, Nightingale PG, Raza K. Beliefs about medicines in patients with rheumatoid arthritis and systemic lupus erythematosus: a comparison between patients of South Asian and White British origin. Rheumatology (Oxford, England). 2008;47:690-7.

40. Mardby AC, Akerlind I, Jorgensen T. Beliefs about medicines and self-reported adherence among pharmacy clients. Patient education and counseling. 2007;69:158-64.

41. Nie B, Chapman SCE, Chen Z, Wang X, Wei L. Utilization of the beliefs about medicine questionnaire and prediction of medication adherence in China: A systematic review and metaanalysis. J Psychosom Res. 2019;122:54-68. 
42. Tan CS, Hassali MA, Neoh CF, Saleem F, Horne R. Cultural Adaptation and Linguistic Validation of the Beliefs about Medicines Questionnaire in Malaysia. Value in health regional issues. 2018;15:161-8.

43. Cinar M, Cinar FI, Acikel C, Yilmaz S, Cakar M, Horne R, Simsek I. Reliability and validity of the Turkish translation of the beliefs about medicines questionnaire (BMQ-T) in patients with Behcet's disease. Clin Exp Rheumatol. 2016;34:S46-s51.

44. Tibaldi G, Clatworthy J, Torchio E, Argentero P, Munizza C, Horne R. The utility of the Necessity-Concerns Framework in explaining treatment non-adherence in four chronic illness groups in Italy. Chronic Illness. 2009;5:129-33.

45. Mahler C, Hermann K, Horne R, Jank S, Haefeli WE, Szecsenyi J. Patients' Beliefs about Medicines in a primary care setting in Germany. Journal of Evaluation in Clinical Practice.

2012;18:409-13. 


\section{Supplemental Digital Content}

Table A.1. Overview of questionnaires per sample.

\begin{tabular}{|c|c|c|c|c|}
\hline & Gs1 & Gs2 & RAs & ADs \\
\hline \multicolumn{5}{|c|}{ Attitude towards medication } \\
\hline GAMQ & $x$ & $x$ & $x$ & $x$ \\
\hline BMQ-G & $x$ & $x$ & $x$ & $x$ \\
\hline $\begin{array}{l}\text { Medication attitude } \\
\text { VAS }\end{array}$ & $x$ & $x$ & $x$ & $x$ \\
\hline \multicolumn{5}{|c|}{ Health-related characteristics } \\
\hline SF-12 PCS & $x$ & & $x$ & $x$ \\
\hline SF-12 MCS & $x$ & & $x$ & $x$ \\
\hline POEM & & & & $x$ \\
\hline DAS-44 & & & & \\
\hline Current pain intensity & $x$ & $x$ & & $x$ \\
\hline Current itch intensity & $x$ & & $x$ & $x$ \\
\hline $\begin{array}{l}\text { In treatment for long- } \\
\text { lasting medical or } \\
\text { psychological } \\
\text { complaints or } \\
\text { diseases (other than } \\
\text { RA for RAs and AD for } \\
\text { ADs) }\end{array}$ & $\mathrm{x}$ & $\mathrm{x}$ & & $\mathrm{x}$ \\
\hline $\begin{array}{l}\text { Expectancies regarding } \\
\text { medication }\end{array}$ & $x$ & & & $x$ \\
\hline
\end{tabular}

Note. Gs1: General sample 1, Gs2: General sample 2, RAs: Rheumatoid Arthritis sample, ADs: Atopic dermatitis sample, GAMQ: General Attitude towards Medication Questionnaire, BMQ-G: General scale of the Beliefs about Medicines Questionnaire, VAS: Visual Analogue Scale, SF-12: Short Form 12, PCS: Physical health Composite, MCS: Mental health Composite, POEM: Patient Oriented Eczema Measure, DAS44: Disease Activity Score-44. 
Table A.2. Dutch version of the General Attitude toward Medication Questionnaire (Attitude ten opzichte van Medicijnen Vragenlijst)

Wij willen u nu een aantal vragen stellen over hoe u denkt over medicijnen in het algemeen.

Wij zijn geïnteresseerd in uw mening over medicijnen die u op doktersvoorschrift gebruikt.

Wilt $u$ aangeven in hoeverre $u$ het eens of oneens bent met onderstaande uitspraken?

Er zijn geen goede of foute antwoorden. Wij zijn benieuwd naar uw mening.

1. Ik ben bezorgd over de bijwerkingen van

helemaal
mee
oneens

\section{geen}

duidelijke

mening

o

medicijnen

2. Ik denk dat medicijnen mij goed kunnen helpen tegen klachten

3. Ik ben bang dat medicijnen schadelijk zijn voor mijn lichaam

4. Als ik klachten heb, neem ik daar gemakkelijk medicijnen voor

5. Ik vind het onnatuurlijk om medicijnen te gebruiken

6. Ik vertrouw er op dat het veilig is om medicijnen te gebruiken

7. Ik gebruik medicijnen alleen als er echt geen andere mogelijkheid is

8. Ik heb er geen moeite mee om medicijnen te gebruiken als ik klachten heb

9. Ik onderga mijn klachten liever dan dat ik medicijnen gebruik

10. Ik vertrouw op de werkzaamheid van medicijnen

11. $\mathrm{lk}$ ben bang verslaafd te raken als ik medicijnen langdurig gebruik

12. Voor mij wegen de voordelen van medicijnen op tegen de nadelen

$\begin{array}{rr}\text { mee eens } & \text { helemaal } \\ \text { mee eens }\end{array}$

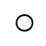

O

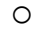

0

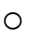

$\bigcirc$

○

$\bigcirc$

O

○

0

0

O

○ 
Table A.3. Demographic and health-related characteristics for each sample.

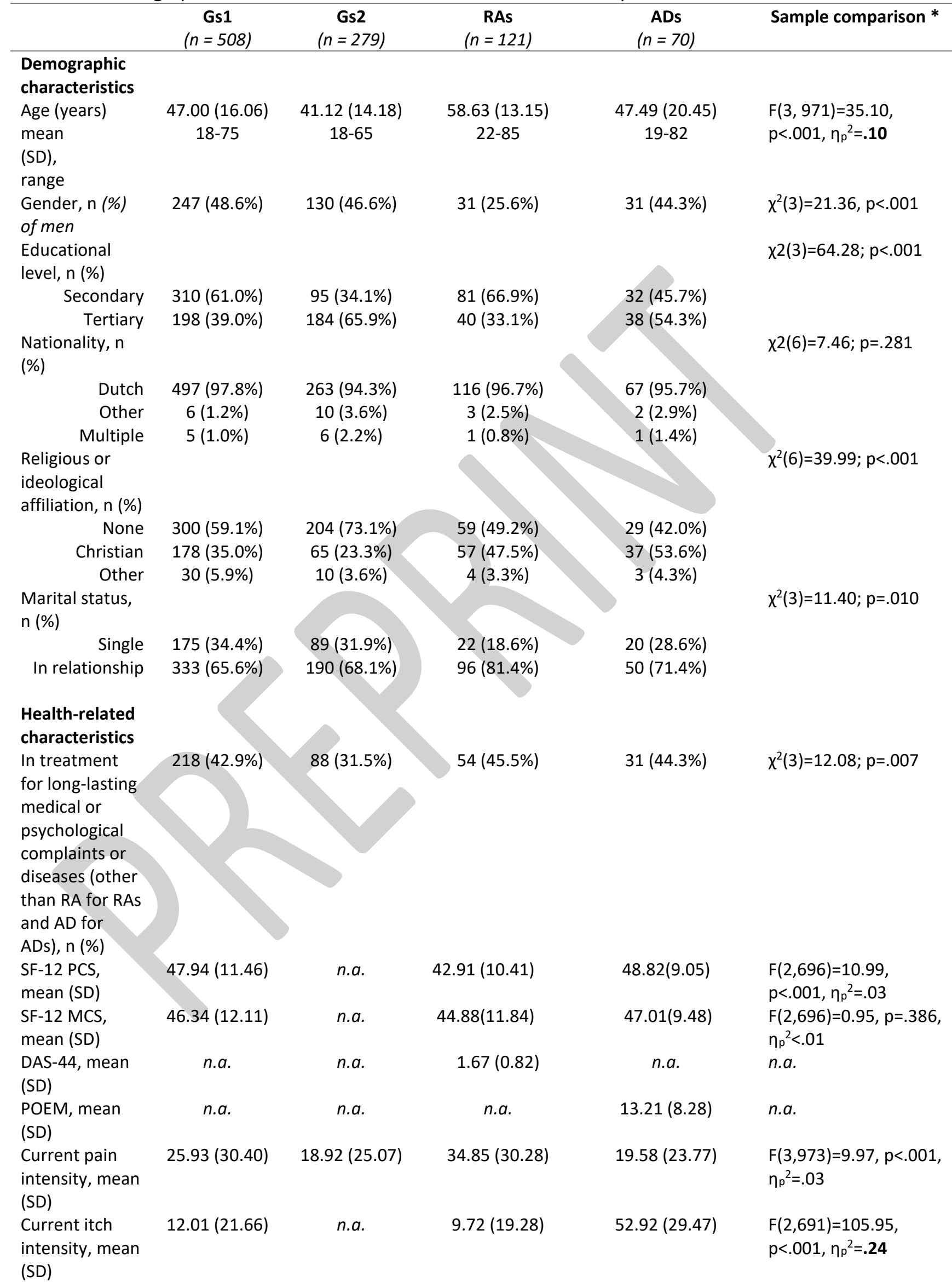




\begin{tabular}{|c|c|c|c|c|c|}
\hline $\begin{array}{l}\text { Expectancies } \\
\text { regarding } \\
\text { medication }\end{array}$ & & & & & \\
\hline $\begin{array}{l}\text { Expected } \\
\text { effectiveness of } \\
\text { medication for } \\
\text { pain relief, } \\
\text { mean (SD) }\end{array}$ & $\begin{array}{c}67.85 \\
(13.42)\end{array}$ & n.a. & $\begin{array}{c}62.81 \\
(12.02)\end{array}$ & $\begin{array}{c}62.50 \\
(14.86)\end{array}$ & $\begin{array}{l}F(2,671)=9.35, p<.001, \\
\eta_{p}^{2}=.03\end{array}$ \\
\hline $\begin{array}{l}\text { Expected } \\
\text { effectiveness of } \\
\text { medication for } \\
\text { itch relief, } \\
\text { mean (SD) }\end{array}$ & $\begin{array}{c}63.04 \\
(15.37)\end{array}$ & n.a. & $\begin{array}{c}60.66 \\
(14.81)\end{array}$ & $\begin{array}{c}57.21 \\
(17.93)\end{array}$ & $\begin{array}{l}(F(2,669)=4.21, \\
p=.014, \eta_{p}^{2}=.01\end{array}$ \\
\hline $\begin{array}{l}\text { Expected side } \\
\text { effects of } \\
\text { medication, } \\
\text { mean (SD) }\end{array}$ & $48.20(12.62)$ & n.a. & $51.93(12.36)$ & 48.03 (11.49) & $\begin{array}{l}F(2,665)=2.97 \\
p=.052, \eta_{p}^{2}=.01\end{array}$ \\
\hline
\end{tabular}

Note: Gs1: General sample 1, Gs2: General sample 2, RAs: Rheumatoid Arthritis sample, ADs: Atopic dermatitis sample. Available data are reported, missing values were disregarded from analyses. SF-12 PCS: short form 12 physical component score, SF-12 MCS: short form 12 mental component score, DAS-44: disease activity score, POEM: patient oriented eczema measure, n.a.: not assessed, SD: standard deviation. 
Table A.4. Cronbach's alpha of the GAMQ total scale if item omitted.

\begin{tabular}{|c|c|c|c|c|}
\hline Item & Gs1 & Gs2 & RAs & ADs \\
\hline $\begin{array}{l}\text { 1) I am concerned about the side } \\
\text { effects of medication. (rev) }\end{array}$ & .84 & .82 & .76 & .80 \\
\hline $\begin{array}{l}\text { 2) I think that medication can help } \\
\text { with my symptoms. }\end{array}$ & .83 & .82 & .77 & .81 \\
\hline $\begin{array}{l}\text { 3) I am afraid that medication has a } \\
\text { harmful effect on my body. (rev) }\end{array}$ & .83 & .82 & .76 & .80 \\
\hline $\begin{array}{l}\text { 4) If I have symptoms, I readily take } \\
\text { medication for them. }\end{array}$ & .83 & .82 & .76 & .79 \\
\hline $\begin{array}{l}\text { 5) I find it unnatural to take } \\
\text { medication. (rev) }\end{array}$ & .82 & .82 & .74 & .77 \\
\hline $\begin{array}{l}\text { 6) I trust that it is safe to take } \\
\text { medication. }\end{array}$ & .83 & .82 & .76 & .78 \\
\hline $\begin{array}{l}\text { 7) I only take medication if there is } \\
\text { absolutely no other option. (rev) }\end{array}$ & .84 & & .79 & .80 \\
\hline $\begin{array}{l}\text { 8) I have no problem with taking } \\
\text { medication if I have symptoms. }\end{array}$ & .82 & & .75 & .78 \\
\hline $\begin{array}{l}\text { 9) I would rather endure my } \\
\text { symptoms than take medication. (rev) }\end{array}$ & .82 & & & .78 \\
\hline $\begin{array}{l}\text { 10) I trust in the effectiveness of } \\
\text { medication. }\end{array}$ & & & & .79 \\
\hline $\begin{array}{l}\text { 11) I am afraid of becoming addicted if } \\
\text { I take medication for an extended } \\
\text { period. (rev) }\end{array}$ & & & .78 & .82 \\
\hline $\begin{array}{l}\text { 12) For me the advantages of } \\
\text { medication outweigh the } \\
\text { disadvantages. }\end{array}$ & .83 & .82 & .76 & .81 \\
\hline Total scale & .84 & .83 & .78 & .81 \\
\hline
\end{tabular}

Note: Gs1: General sample 1, Gs2: General sample 2, RAs: Rheumatoid Arthritis sample, ADs: Atopic dermatitis sample. (rev) indicates items for which scores were reversed.

Table A.5. Cronbach's alpha of the GAMQ subscale Trust if item omitted.

\begin{tabular}{lcccc}
\hline Item & Gs1 & Gs2 & RAs & ADs \\
\hline $\begin{array}{l}\text { 2) I think that medication can help } \\
\text { with my symptoms. }\end{array}$ & .77 & .76 & .71 & .72 \\
$\begin{array}{l}\text { 6) I trust that it is safe to take } \\
\text { medication. }\end{array}$ & .78 & .74 & .69 & .66 \\
$\begin{array}{l}\text { 8) I have no problem with taking } \\
\text { medication if I have symptoms. }\end{array}$ & .80 & .74 & .70 & .67 \\
$\begin{array}{l}\text { 10) I trust in the effectiveness of } \\
\text { medication. }\end{array}$ & .76 & .74 & .67 & .66 \\
$\begin{array}{l}\text { 12) For me the advantages of } \\
\text { medication outweigh the }\end{array}$ & & & & \\
disadvantages. & .78 & .74 & .67 & .75 \\
\hline \begin{tabular}{l} 
Total scale \\
\hline
\end{tabular} & .81 & .78 & .73 & .74 \\
\hline
\end{tabular}

Note: Gs1: General sample 1, Gs2: General sample 2, RAs: Rheumatoid Arthritis sample, ADs: Atopic dermatitis sample. 
Table A.6.Cronbach's alpha of the GAMQ subscale Concerns if item omitted.

\begin{tabular}{lcccc}
\hline Item & Gs1 & Gs2 & RAs & ADs \\
\hline $\begin{array}{l}\text { 1) I am concerned about the side } \\
\text { effects of medication. }\end{array}$ & .55 & .37 & .35 & .45 \\
$\begin{array}{l}\text { 3) I am afraid that medication has a } \\
\text { harmful effect on my body. }\end{array}$ & .48 & .41 & .50 & .48 \\
$\begin{array}{l}\text { 11) I am afraid of becoming addicted if } \\
\text { I take medication for an extended } \\
\text { period. }\end{array}$ & .74 & .68 & .80 & .85 \\
\hline \multicolumn{1}{l}{ Total scale } & .69 & .59 & .67 & .71 \\
\hline
\end{tabular}

Note: Gs1: General sample 1, Gs2: General sample 2, RAs: Rheumatoid Arthritis sample, ADs: Atopic dermatitis sample.

Table A.7. Cronbach's alpha of the GAMQ subscale Reluctance if item omitted.

\begin{tabular}{lcccc}
\hline Item & Gs1 & Gs2 & RAs & ADs \\
\hline $\begin{array}{l}\text { 5) I find it unnatural to take } \\
\text { medication. }\end{array}$ & .49 & .56 & .35 & .51 \\
$\begin{array}{l}\text { 7) I only take medication if there is } \\
\text { absolutely no other option. }\end{array}$ & .71 & .60 & .60 & .65 \\
$\begin{array}{l}\text { 9) I would rather endure my } \\
\text { symptoms than take medication. }\end{array}$ & .46 & .56 & .38 & .51 \\
\hline Total scale & .67 & .67 & .56 & .66 \\
\hline
\end{tabular}

Note: Gs1: General sample 1, Gs2: General sample 2, RAs: Rheumatoid Arthritis sample, ADs: Atopic dermatitis sample. 
Table A.8. Associations of the GAMQ with expected medication effects, demographic and health variables.

\begin{tabular}{|c|c|c|c|c|c|c|c|c|c|c|c|c|c|c|c|c|}
\hline & \multicolumn{4}{|c|}{ Gs1 $(n=508)$} & \multicolumn{4}{|c|}{ Gs2 $(n=279)$} & \multicolumn{4}{|c|}{ RAs $(n=121)$} & \multicolumn{4}{|c|}{ ADs $(n=70)$} \\
\hline & Total & Trust & $\begin{array}{l}\text { Concern } \\
\mathrm{s}\end{array}$ & $\begin{array}{l}\text { Reluctan } \\
\text { ce }\end{array}$ & Total & Trust & $\begin{array}{l}\text { Concern } \\
\mathrm{s}\end{array}$ & $\begin{array}{l}\text { Reluctan } \\
\text { ce }\end{array}$ & Total & Trust & $\begin{array}{l}\text { Concern } \\
\mathrm{s}\end{array}$ & $\begin{array}{l}\text { Reluctan } \\
\text { ce }\end{array}$ & Total & Trust & $\begin{array}{l}\text { Concern } \\
\mathrm{s}\end{array}$ & $\begin{array}{l}\text { Reluctan } \\
\text { ce }\end{array}$ \\
\hline \multicolumn{17}{|l|}{$\begin{array}{l}\text { Demographic } \\
\text { characteristics }\end{array}$} \\
\hline Age (years), $r$ & .04 & $.12^{*}$ & $<.01$ & -.01 & .02 & .02 & -.01 & -.03 & .02 & -.02 & $<.01$ & -.05 & -.03 & .01 & .06 & .06 \\
\hline Gender, $n_{p}^{2}$ & $.02^{* *}$ & $.01^{* *}$ & $.03^{* * *}$ & $.01^{*}$ & .01 & .01 & .01 & .00 & .03 & $.03^{*}$ & .00 & .03 & .00 & .00 & .04 & .00 \\
\hline Men, mean (SD) & $\begin{array}{l}40.94 \\
(6.47)\end{array}$ & $\begin{array}{l}19.14 \\
(3.09)\end{array}$ & $\begin{array}{l}8.28 \\
(2.36)\end{array}$ & $\begin{array}{l}8.60 \\
(2.21)\end{array}$ & $\begin{array}{l}38.78 \\
(7.55)\end{array}$ & $\begin{array}{l}18.19 \\
(3.50)\end{array}$ & $\begin{array}{l}8.85 \\
(2.51)\end{array}$ & $\begin{array}{l}9.11 \\
(2.45)\end{array}$ & $\begin{array}{l}41.52 \\
(6.53)\end{array}$ & $\begin{array}{l}20.03 \\
(3.04)\end{array}$ & $\begin{array}{l}9.00 \\
(2.53)\end{array}$ & $\begin{array}{l}8.23 \\
(2.32)\end{array}$ & $\begin{array}{l}39.97 \\
(7.64)\end{array}$ & $\begin{array}{l}19.26 \\
(3.36)\end{array}$ & $\begin{array}{l}9.35 \\
(2.78)\end{array}$ & $\begin{array}{l}8.77 \\
(2.68)\end{array}$ \\
\hline Women, mean (SD) & $\begin{array}{l}38.79 \\
(7.34)\end{array}$ & $\begin{array}{l}18.37 \\
(3.17)\end{array}$ & $\begin{array}{l}9.21 \\
(2.59)\end{array}$ & $\begin{array}{l}9.10 \\
(2.39)\end{array}$ & $\begin{array}{l}37.50 \\
(6.92)\end{array}$ & $\begin{array}{l}17.65 \\
(3.08)\end{array}$ & $\begin{array}{l}9.28 \\
(2.32)\end{array}$ & $\begin{array}{l}9.34 \\
(2.44)\end{array}$ & $\begin{array}{l}39.29 \\
(6.05)\end{array}$ & $\begin{array}{l}18.87 \\
(2.74)\end{array}$ & $\begin{array}{l}9.14 \\
(2.48)\end{array}$ & $\begin{array}{l}9.03 \\
(2.17)\end{array}$ & $\begin{array}{l}40.69 \\
(6.00)\end{array}$ & $\begin{array}{l}18.95 \\
(2.73)\end{array}$ & $\begin{array}{l}8.26 \\
(2.36)\end{array}$ & $\begin{array}{l}8.67 \\
(2.14)\end{array}$ \\
\hline Educational level, $\eta_{p}^{2}$ & .01 & .01 & .00 & .00 & .00 & .00 & .00 & .00 & .01 & .02 & .00 & .01 & .02 & .01 & .04 & .00 \\
\hline Secondary, mean (SD) & $\begin{array}{l}40.23 \\
(6.96)\end{array}$ & $\begin{array}{l}18.93 \\
(3.12)\end{array}$ & $\begin{array}{l}8.68 \\
(2.48)\end{array}$ & $\begin{array}{l}8.80 \\
(2.26)\end{array}$ & $\begin{array}{l}37.46 \\
(7.20)\end{array}$ & $\begin{array}{l}17.61 \\
(3.47)\end{array}$ & $\begin{array}{l}9.24 \\
(2.55)\end{array}$ & $\begin{array}{l}9.39 \\
(2.48)\end{array}$ & $\begin{array}{l}40.33 \\
(6.05)\end{array}$ & $\begin{array}{l}19.43(2 . \\
71)\end{array}$ & $\begin{array}{l}9.14(2.6 \\
0)\end{array}$ & $\begin{array}{l}8.69(2.2 \\
6)\end{array}$ & $\begin{array}{l}39.38 \\
(7.42)\end{array}$ & $\begin{array}{l}18.78 \\
(3.25)\end{array}$ & $\begin{array}{l}9.28 \\
(2.99)\end{array}$ & $\begin{array}{l}8.88 \\
(2.12)\end{array}$ \\
\hline Tertiary, mean (SD) & $\begin{array}{l}39.22 \\
(7.05)\end{array}$ & $\begin{array}{l}18.44 \\
(3.19)\end{array}$ & $\begin{array}{l}8.88 \\
(2.59)\end{array}$ & $\begin{array}{l}8.94 \\
(2.41)\end{array}$ & $\begin{array}{l}38.35 \\
(7.19)\end{array}$ & $\begin{array}{l}18.05(3 . \\
19)\end{array}$ & $\begin{array}{l}8.99 \\
(2.35)\end{array}$ & $\begin{array}{l}9.15(2.4 \\
3)\end{array}$ & $\begin{array}{l}38.90 \\
(6.54)\end{array}$ & $\begin{array}{l}18.62 \\
(3.08)\end{array}$ & $\begin{array}{l}9.05 \\
(2.26)\end{array}$ & $\begin{array}{l}9.10 \\
(2.17)\end{array}$ & $\begin{array}{l}41.21 \\
(6.06)\end{array}$ & $\begin{array}{l}19.34 \\
(2.80)\end{array}$ & $\begin{array}{l}8.29 \\
(2.14)\end{array}$ & $\begin{array}{l}8.58 \\
(2.60)\end{array}$ \\
\hline Nationality, $\eta_{p}^{2}$ & .01 & .01 & .01 & .01 & .00 & .01 & .01 & .01 & .02 & .02 & .02 & .03 & .03 & .04 & .03 & .03 \\
\hline Dutch, mean (SD) & $\begin{array}{l}39.86 \\
(6.97)\end{array}$ & $\begin{array}{l}18.76 \\
(3.14)\end{array}$ & $\begin{array}{l}8.75 \\
(2.50)\end{array}$ & $\begin{array}{l}8.86 \\
(2.32)\end{array}$ & $\begin{array}{l}38.14 \\
(7.24)\end{array}$ & $\begin{array}{l}17.98 \\
(3.30)\end{array}$ & $\begin{array}{l}9.12 \\
(2.41)\end{array}$ & $\begin{array}{l}9.23 \\
(2.43)\end{array}$ & $\begin{array}{l}39.96 \\
(6.21)\end{array}$ & $\begin{array}{l}19.22 \\
(2.87)\end{array}$ & $\begin{array}{l}9.12 \\
(2.50)\end{array}$ & $\begin{array}{l}8.79 \\
(2.20)\end{array}$ & $\begin{array}{l}40.52 \\
(6.73)\end{array}$ & $\begin{array}{l}19.15 \\
(3.01)\end{array}$ & $\begin{array}{l}8.66 \\
(2.56)\end{array}$ & $\begin{array}{l}8.69 \\
(2.39)\end{array}$ \\
\hline Other, mean (SD) & $\begin{array}{l}35.17 \\
(9.83)\end{array}$ & $\begin{array}{l}16.67 \\
(4.76)\end{array}$ & $\begin{array}{l}10.17 \\
(3.66)\end{array}$ & $\begin{array}{l}9.50 \\
(2.35)\end{array}$ & $\begin{array}{l}36.30 \\
(6.78)\end{array}$ & $\begin{array}{l}16.70 \\
(2.67)\end{array}$ & $\begin{array}{l}8.80 \\
(2.53)\end{array}$ & $\begin{array}{l}9.80 \\
(2.70)\end{array}$ & $\begin{array}{l}35.67 \\
(4.93)\end{array}$ & $\begin{array}{l}16.67 \\
(1.53)\end{array}$ & $\begin{array}{l}8.00 \\
(1.73)\end{array}$ & $\begin{array}{l}10.33 \\
(2.31)\end{array}$ & $\begin{array}{l}40.50 \\
(4.95)\end{array}$ & $\begin{array}{l}19.50 \\
(0.71)\end{array}$ & $\begin{array}{l}11.00 \\
(4.24)\end{array}$ & $\begin{array}{l}8.00 \\
(0.00)\end{array}$ \\
\hline Multiple, mean (SD) & $\begin{array}{l}42.80 \\
(5.40)\end{array}$ & $\begin{array}{l}19.20 \\
(2.05)\end{array}$ & $\begin{array}{l}7.60 \\
(2.79)\end{array}$ & $\begin{array}{l}7.20 \\
(1.64)\end{array}$ & $\begin{array}{l}39.33 \\
(8.21)\end{array}$ & $\begin{array}{l}16.67 \\
(3.67)\end{array}$ & $\begin{array}{l}7.83 \\
(2.56)\end{array}$ & $\begin{array}{l}8.33 \\
(2.94)\end{array}$ & $\begin{array}{l}33.00 \\
(n=1)\end{array}$ & $\begin{array}{l}19.00 \\
(n=1)\end{array}$ & $\begin{array}{l}12.00 \\
(n=1)\end{array}$ & $\begin{array}{l}12.00 \\
(n=1)\end{array}$ & $\begin{array}{l}30.00 \\
(n=1)\end{array}$ & $\begin{array}{l}14.00 \\
(n=1)\end{array}$ & $\begin{array}{l}10.00 \\
(n=1)\end{array}$ & $\begin{array}{l}12.00 \\
(n=1)\end{array}$ \\
\hline $\begin{array}{l}\text { Religious or ideological } \\
\text { affiliation, } \eta_{\mathrm{p}}{ }^{2}\end{array}$ & .01 & .00 & .01 & .01 & .00 & .00 & .00 & .00 & $.07 *$ & $.07 *$ & .02 & .04 & .06 & .02 & .07 & .04 \\
\hline None, mean (SD) & $\begin{array}{l}40.19 \\
(6.79)\end{array}$ & $\begin{array}{l}18.74 \\
(3.05)\end{array}$ & $\begin{array}{l}8.67 \\
(2.43)\end{array}$ & $\begin{array}{l}8.66 \\
(2.28)\end{array}$ & $\begin{array}{l}38.11 \\
(7.42)\end{array}$ & $\begin{array}{l}17.95 \\
(3.41)\end{array}$ & $\begin{array}{l}9.03 \\
(2.52)\end{array}$ & $\begin{array}{l}9.31 \\
(2.49)\end{array}$ & $\begin{array}{l}39.69 \\
(5.46)\end{array}$ & $\begin{array}{l}19.20 \\
(2.62)\end{array}$ & $\begin{array}{l}9.34 \\
(2.25)\end{array}$ & $\begin{array}{l}8.93 \\
(2.09)\end{array}$ & $\begin{array}{l}41.21(6 . \\
49)\end{array}$ & $\begin{array}{l}19.45 \\
(2.80)\end{array}$ & $\begin{array}{l}8.31 \\
(2.51)\end{array}$ & $\begin{array}{l}8.69 \\
(2.47)\end{array}$ \\
\hline Christian, mean (SD) & $\begin{array}{l}39.61 \\
(7.18)\end{array}$ & $\begin{array}{l}18.87 \\
(3.10)\end{array}$ & $\begin{array}{l}8.78 \\
(2.55)\end{array}$ & $\begin{array}{l}9.15 \\
(2.37)\end{array}$ & $\begin{array}{l}38.08 \\
(6.05)\end{array}$ & $\begin{array}{l}17.83 \\
(2.83)\end{array}$ & $\begin{array}{l}9.26 \\
(1.86)\end{array}$ & $\begin{array}{l}9.00 \\
(2.22)\end{array}$ & $\begin{array}{l}40.49 \\
(6.57)\end{array}$ & $\begin{array}{l}19.37 \\
(2.77)\end{array}$ & $\begin{array}{l}8.79 \\
(2.74)\end{array}$ & $\begin{array}{l}8.63 \\
(2.30)\end{array}$ & $\begin{array}{l}40.51 \\
(6.83)\end{array}$ & $\begin{array}{l}19.05 \\
(3.16)\end{array}$ & $\begin{array}{l}8.84 \\
(2.62)\end{array}$ & $\begin{array}{l}8.54 \\
(2.38)\end{array}$ \\
\hline Other, mean (SD) & $\begin{array}{l}37.63 \\
(7.84)\end{array}$ & $\begin{array}{l}18.00 \\
(4.30)\end{array}$ & $\begin{array}{l}9.53 \\
(3.10)\end{array}$ & $\begin{array}{l}9.00 \\
(2.24)\end{array}$ & $\begin{array}{l}38.00 \\
(10.69)\end{array}$ & $\begin{array}{l}17.40 \\
(3.75)\end{array}$ & $\begin{array}{l}8.90 \\
(3.48)\end{array}$ & $\begin{array}{l}9.10 \\
(3.03)\end{array}$ & $\begin{array}{l}31.25 \\
(6.18)\end{array}$ & $\begin{array}{l}15.25 \\
(5.12)\end{array}$ & $\begin{array}{l}10.50 \\
(1.73)\end{array}$ & $\begin{array}{l}11.00 \\
(1.83)\end{array}$ & $\begin{array}{l}33.00 \\
(4.00)\end{array}$ & $\begin{array}{l}17.67 \\
(2.08)\end{array}$ & $\begin{array}{c}11.67 \\
(2.08)\end{array}$ & $\begin{array}{l}11.00 \\
(0.00)\end{array}$ \\
\hline Marital status, $\eta_{p}^{2}$ & .00 & .00 & .00 & .00 & .00 & .01 & .00 & .00 & .00 & .00 & .01 & .00 & .04 & .02 & .03 & .03 \\
\hline Single, mean (SD) & $\begin{array}{l}39.55 \\
(6.61)\end{array}$ & $\begin{array}{l}18.61 \\
(3.03)\end{array}$ & $\begin{array}{l}8.88 \\
(2.62)\end{array}$ & $\begin{array}{l}8.85 \\
(2.22)\end{array}$ & $\begin{array}{l}37.51 \\
(7.89)\end{array}$ & $\begin{array}{l}17.52 \\
(3.56)\end{array}$ & $\begin{array}{l}9.01 \\
(2.64)\end{array}$ & $\begin{array}{l}9.44 \\
(2.59)\end{array}$ & $\begin{array}{l}40.23 \\
(6.71)\end{array}$ & $\begin{array}{l}19.27 \\
(2.49)\end{array}$ & $\begin{array}{l}8.55 \\
(3.05)\end{array}$ & $\begin{array}{l}8.95 \\
(1.91)\end{array}$ & $\begin{array}{l}42.45 \\
(5.96)\end{array}$ & $\begin{array}{l}19.80 \\
(2.59)\end{array}$ & $\begin{array}{l}8.05 \\
(2.39)\end{array}$ & $\begin{array}{l}8.05 \\
(2.65)\end{array}$ \\
\hline $\begin{array}{r}\text { In relationship, mean } \\
\text { (SD) }\end{array}$ & $\begin{array}{l}39.98 \\
(7.21)\end{array}$ & $\begin{array}{l}18.81 \\
(3.21)\end{array}$ & $\begin{array}{l}8.70 \\
(2.47)\end{array}$ & $\begin{array}{l}8.86 \\
(2.37)\end{array}$ & $\begin{array}{l}38.38 \\
(6.91)\end{array}$ & $\begin{array}{l}18.08 \\
(3.15)\end{array}$ & $\begin{array}{l}9.11 \\
(2.31)\end{array}$ & $\begin{array}{l}9.13 \\
(2.37)\end{array}$ & $\begin{array}{l}39.50 \\
(5.85)\end{array}$ & $\begin{array}{l}19.05 \\
(2.91)\end{array}$ & $\begin{array}{l}9.30 \\
(2.28)\end{array}$ & $\begin{array}{l}8.90 \\
(2.23)\end{array}$ & $\begin{array}{l}39.54 \\
(6.90)\end{array}$ & $\begin{array}{l}18.80 \\
(3.14)\end{array}$ & $\begin{array}{l}9.02 \\
(2.64)\end{array}$ & $\begin{array}{l}8.98 \\
(2.24)\end{array}$ \\
\hline
\end{tabular}




\begin{tabular}{|c|c|c|c|c|c|c|c|c|c|c|c|c|c|c|c|c|}
\hline \multicolumn{17}{|l|}{ Health variables } \\
\hline $\begin{array}{l}\text { long-lasting medical or } \\
\text { psychological complaints } \\
1, \eta_{p}{ }^{2}\end{array}$ & $.02^{* *}$ & $.04^{* * *}$ & .01 & $.02^{* *}$ & .00 & .01 & .01 & .00 & .00 & .00 & .00 & .00 & .05 & $.09^{*}$ & .00 & .03 \\
\hline \multirow{2}{*}{ No, mean (SD) } & & & & & & & & 0.32 & 397216 & 1915 & & & & & & \\
\hline & $(7.06)$ & $(3.28)$ & $(2.40)$ & $(2.33)$ & $(7.68)$ & $(3.45)$ & $(2.47)$ & $(2.58)$ & $52)$ & $(3.09)$ & $(2.44)$ & $\begin{array}{l}0.00 \\
(2.24)\end{array}$ & $\begin{array}{l}39.00 \\
(7.27)\end{array}$ & $\begin{array}{l}10.31 \\
(3.10)\end{array}$ & $\begin{array}{c}0.02 \\
(2.49)\end{array}$ & $(2.62)$ \\
\hline \multirow[t]{2}{*}{ Yes, mean (SD) } & 40.81 & 19.45 & 8.97 & 8.48 & 38.58 & 18.36 & 9.42 & 9.01 & 40.31 & 19.20 & $9.02(2.5$ & 8.79 & 42.00 & 20.06 & 8.65 & 8.29 \\
\hline & $(6.83)$ & $(2.82)$ & (2.67) & (2.25) & (6.15) & (2.87) & (2.28) & (2.11) & $(6.00)$ & (2.59) & 8) & (2.24) & (5.69) & (2.61) & (2.75) & (2.00) \\
\hline SF-12 PCS, r & .00 & $-.08^{*}$ & $-.18^{*}$ & .04 & n.a. & n.a. & n.a. & n.a. & $.20^{*}$ & .14 & -.17 & $-.20^{*}$ & -.15 & -.12 & -.03 & .21 \\
\hline SF-12 MCS, $r$ & .06 & .04 & $-.23^{*}$ & .07 & n.a. & n.a. & n.a. & n.a. & .14 & -.01 & $-.29^{*}$ & -.15 & -.06 & -.04 & -.10 & .19 \\
\hline DAS44, $r$ & n.a. & n.a. & n.a. & n.a. & n.a. & n.a. & n.a. & n.a. & $-.24^{*}$ & -.21 & .16 & $.23^{*}$ & n.a. & n.a. & n.a. & n.a. \\
\hline POEM, r & n.a. & n.a. & n.a. & n.a. & n.a. & n.a. & n.a. & n.a. & & n.a. & n.a. & n.a. & .01 & .08 & .10 & -.03 \\
\hline Current pain intensity, $r$ & -.02 & .03 & $.14^{*}$ & -.01 & .00 & .02 & .09 & & & & .08 & .07 & .08 & .13 & $.20^{*}$ & -.24 \\
\hline Current itch intensity, $r$ & .02 & .00 & .04 & -.05 & n.a. & n.a. & & & 9 & 04 & $.17^{*}$ & .08 & -.08 & .05 & .20 & .08 \\
\hline \multicolumn{17}{|l|}{$\begin{array}{l}\text { Expectancies regarding } \\
\text { medication }\end{array}$} \\
\hline $\begin{array}{l}\text { Expected effectiveness of } \\
\text { medication [in general] } \\
\text { for pain relief, } r\end{array}$ & $.26^{*}$ & $.30^{*}$ & $-.14^{*}$ & $-.16^{*}$ & n.a. & n.a. & & & $.30^{*}$ & .18 & $-.23^{*}$ & $-.21^{*}$ & .07 & .21 & .10 & -.05 \\
\hline $\begin{array}{l}\text { Expected effectiveness of } \\
\text { medication [in general] } \\
\text { for itch relief, } r\end{array}$ & $.24^{*}$ & $.27^{*}$ & $-.15^{*}$ & $-.13^{*}$ & n.a. & T.d. & n.a. & n.a. & .08 & -.03 & -.07 & -.12 & $.35^{*}$ & $.48^{*}$ & -.03 & $-.26^{*}$ \\
\hline $\begin{array}{l}\text { Expected side effects of } \\
\text { medication [in general], } r\end{array}$ & $-.23^{*}$ & $-.20^{*}$ & $.22^{*}$ & $.14^{*}$ & n.a. & n.a. & n.a. & n.a. & $-.24^{*}$ & -.16 & $.27^{*}$ & .14 & $-.42^{*}$ & $-.36^{*}$ & .24 & $.36^{*}$ \\
\hline
\end{tabular}

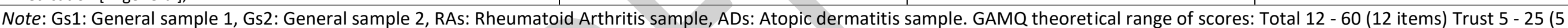

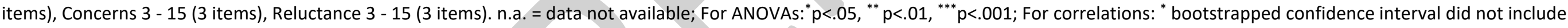

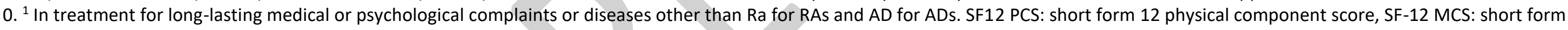
12 mental component score, DAS44: disease activity score, POEM: patient oriented eczema measure. Medium and large effect sizes are printed in bold. 